\title{
PERKEMBANGAN PENDIDIKAN ISLAM DI INDONESIA
}

\author{
Abdul Basyit \\ basyit71@yahoo.com \\ (Dosen Fakultas Agama Islam, Universitas Muhammadiyah Tangerang)
}

\begin{abstract}
Abstrak:
Perkembangan Pendidikan Islam Di Indonesia. Pada awalnya bersifat informal, yakni melalui interaksi inter-personal yang berlangsung dalam berbagai kesempatan seperti aktivitas perdagangan da'wah bil hal atau keteladanan. Lembaga pendidikan islam tradisional di Nusantara antara lain yaitu: Masjid, Langgar, Pesantren adalah lembaga pendidikan dan pengajaran agama. Madrasah merupakan perkembangan lebih lanjut atau pembaruan dari pesantren atau surau yang berlanjut pada Perguruan Tinggi Agama. Sekolah Islam dan madrasah unggulan menambahkan penekanan pada religiusitas dan kesalehan melalui berbagai matpel keislaman. Secara sederhana, proses pendidikan yang dikembangkan di madrasah dan sekolah Islam unggulan (terpadu) bertujuan untuk mencetak alumni yang "cerdas" dan "berakhlak mulia". Faktor yang menumbuh kembangkan keberadaan sekolah dan madrasah terpadu adalah kesadaran sebagian muslim untuk mendesain system pendidikan unggul, menurunnya proses dan hasil pendidikan di sekolahsekolah umum, skeptisnya sebagian masyarakat terhadap proses dan hasil pendidikan pada lembaga-lembaga pendidikan.
\end{abstract}

Kata Kunci: Perkembangan, Pendidikan. Indonesia.

\section{A. Pendahuluan}

Perjalanan Sejarah Perkembangan Pendidikan Islam di Indonesia seiring dengan masuknya Islam ke bumi Nusantara yang ditransmisikan melalui jaringan ulama' Timur Tengah dan Nusantara pada abad ke-17 yang tercipta secara ekstensif melalui tradisi keilmuan. ${ }^{1}$

\footnotetext{
${ }^{1}$ Selama ini terdapat anggapan bahwa hubungan antara Islam di Nusantara dengan Timur Tengah lebih bersifat politis ketimbang keagamaan. Azyumardi menampik anggapan ini dan membuktikan bahwa sejak abad ke-17 hubungan di antara kedua wilayah Muslim ini umumnya bersifat keagamaan dan keilmuan, meski tidak dapat dinafikan adanya hubungan politik antara beberapa kerajaan Muslim Nusantara, misalnya dengan Dinasti Utsmani. Setidaknya dengan melihat banyaknya pelajar dari Indonesia yang menuntut ilmu di Haromain yang kemudian mentransmisika keilmuannya ke bumi Nusantara. Untuk lebih lengkap mengenai hal ini, baca lebih lanjut, Azyumardi Azra, Jaringan Ulama Timur Tengah dan Kepulauan Nusantara Abad XVII dan XVIII (Bandung: Mizan, 1998).
}

Tradisi keilmuan di kalangan ulama sepanjang sejarah Islam berkaitan erat dengan lembaga-lembaga sosial keagamaan dan pendidikan seperti madrasah, ribath bahkan rumah guru. Dilandasi hal ini, maka lembaga pendidikan Islam di Indonesia pada masa awal mensinergikan antara corak indigenous keindonesiaan (dengan tradisi Hindu dan Budha) dengan nuansa Timur Tengah, seperti berdirinya surau, langgar, musholla, masjid dan pesantren. ${ }^{2}$ yang kemudian mengalami modernisasi seperti madrasah dan perguruan Tinggi. Meskipun sebagaian ahli dan sejarawan Islam berasumsi bahwa masuknya Islam ke

\footnotetext{
${ }^{2}$ Nurcholish Madjid, "Merumuskan Kembali Tujuan Pendidikan Pesantren" dalam M. Dawam Rahardjo (ed), Pergulatan Dunia Pesantren: Membangun dari Bawah (Jakarta: P3M, 1985, h. 3. Lihat juga, Nor Huda, Islam Nusantara: Sejarah Intelektual Islam di Indonesia (Yogyakarta: ArRuzz Media, 2007), hlm. 378
} 
Indonesia pada abad ke-7 Masehi. ${ }^{3}$ dan dapat tersebar serta berkembang pada abad ke-15 yang kemudian secara resmi dianut oleh mayoritas rakyat dan penguasa pada abad ke-16, bukan berarti lembaga pendidikan Islam sudah tersistem pada masa-masa itu. Masih menguatnya sistem ajaran Hindu dan Budha yang menjadi kendala tersendiri bagi perkembangan pendidikan agama Islam, menjadikan lembaga-lembaga pendidikan Islam pada masa awal masih banyak mengadopsi sistem Hindu. Surau dan Pondok Pesantren awalnya meupakan tempat belajar dengan sistem Hindu, namun dalam perkembangan selanjutnya diislamisasi sesuai dengan lembaga pendidikan Islam. Hingga akhirnya pada awal abad 19 oleh para sejarawan barulah disiyalir sebagai awal perkembangan pendidikan Islam di Indonesia. Abad ini dianggap demikian sebab saat itu merupakan babak baru kondisi pendidikan Islam di Indonesia, pertumbuhan dan perkembangannya begitu pesat, serta pengelolaan juga terorganisir secara rapi. Kondisi ini disebabkan masuknya pemikiran pembaruan dari Timur Tengah serta sudah adanya kompetisi dengan pendidikan modern oleh pemerintah Belanda. ${ }^{4}$

Kedatangan Islam di Nusantara memang hampir bersamaan dengan, atau

\footnotetext{
${ }^{3}$ Terdapat pandangan yang berbeda di kalanganpara ahli mengenai kedatanganIslam di Nusantara. Perbedaan pandangan itu setidaknya dipengaruhi oleh sudut pandang terhadap tempat asal kedatangan yakni negara yang menjadi perantara, Para pembawa atau pelaku penyebar dan waktu kedatangan. Perbedaan ini pula yang kemudian menghasilkan tiga teori masuknya Islam ke Nusantara, yakni Teori Gujarat, Teori Makkah dan Teori Persia. Lebih lanjut mengenai ketiga teor ini, lihat, Khozin, Jejak-jejak Pendidikan Islam di Indonesia: Rekonstruksi Sejarah Untuk Aksi (Malang: UMM Press, 2006), hlm. 34-44. Bandingkan pula, Azra, Jaringan Ulama, hlm. 2355.

${ }^{4}$ Hasbullah, Dasar-dasar Ilmu Pendidikan (Jakarta: RajaGrafindo Persada, 1999), hlm. 152.
}

segera disusul oleh kedatangan kaum kolonialis Eropa. ${ }^{5}$ Penjajahan Belanda yang berlangsung kurang lebih tiga setengah abad tersebut, kemudian menghalangi gerak dakwah para ulama' dan kyai yang datang dari Timur Tengah. Sebagai contoh dari bentuk penghalangan Belanda terhadap gerak dakwah para ulama' dan kyai Timur Tengah tersebut adalah adanya perlakuan diskriminatif yang diwujudkan dalam bentuk Kebijakan dengan mewajibkan para kyai dan ulama yang akan melakukan pengajaran atau pengajian agar izin dahulu terhadap Belanda, padahal tidak semua ulama atau kiyai juga diberi izin untuk mengajar. Tindakan diskriminatif lainnya juga bahwa kolonial Belanda mempersulit perjalanan ke luar negeri untuk melakukan ibadah haji. Perizinan untuk melakukan perjalanan dari satu provinsi ke provinsi lain untuk pelaksanaan penyebaran agama Islam juga sangat dibatasi. Atas keadaan inilah, maka keadaan pendidikan Islam di Indonesia sangat terhambat dengan kualitas sangat memprihatinkan. Transmisi keilmuan dan interaksi intelektualitas dengan negerinegeri Muslim juga terhenti, sampai ketika Belanda berusaha membuat lembaga pendidikan yang bercorak Barat, umat Islam tidak mau ketinggalan dengan memperkuat lagi peran pesantren yang lebih berupa padepokan dengan penekanan aktifitas pada kegiatan tarekat. ${ }^{6}$

Dalam sistem stratifikasi sosial kolonial yang paling tidak diuntungkan dalam sistem pendidikan colonial adalah mereka yang diidentifikasi oleh Clifford Geertz sebagai golongan santri. Di bawah pimpinan para ulama', golongan santri yang juga disebut sebagai kelompok sosial

${ }^{5}$ Nurcholish Madjid, Islam Doktrin dan Peradaban: Sebuah Telaah Kritis tentang Masalah Keimanan, Kemanusiaan dan Kemodernan (Jakarta: Paramadina, 2000), hlm. xii.

${ }^{6}$ Khozin, Jejak-jejak Pendidikan Islam, hlm.
73 
yang paling banyak melahirkan wirausahawan pribumi itu merupakan golongan yang dalam hal pendidikan modern termasuk paling rendah. ${ }^{7}$ Ketika pemerintah Belanda ingin menyertakan rakyat Hindia Belanda dalam peradaban modern dengan mengenalkan pendidikan modern (Belanda, Barat, Sekuler), para ulama' mengimbanginya dengan mengembangkan dan mendirikan lebih banyak pesantren-pesantren.

\section{B. Pendidikan Islam Pada Masa Permulaan}

Pendidikan Islam di Indonesia pada masa awalnya bersifat informal, yakni melalui interaksi inter-personal yang berlangsung dalam berbagai kesempatan seperti aktivitas perdagangan da'wah bil hal atau keteladanan ${ }^{8}$. Pada konteks ini mempunyai pengaruh besar dalam menarik perhatian dan minat seseorang untuk mengkaji atau memeluk ajaran Islam. Selanjutnya, ketika agama ini kian berkembang, system pendidikan pun mulai berkembang:

\section{System Pendidikan Langgar}

Asal-Usul Langgar, Istilah langgar dipakai untuk menunjuk bangunan kecil biasa-nya berbentuk segi empat seperti bangunan mesjid namun lebih kecil--yang berdiri di sekitar rumah-rumah komunitas muslim. Secara umum bangunan tersebut digunakan sebagai tempat ibadah salat (selain salat jum'at). Oleh karena itu, langgar sering disebut pula musolla (tempat salat). ${ }^{9}$ Selain sebagai tempat salat,

\footnotetext{
${ }^{7}$ Madjid, Islam Doktrin dan Peradaban, hlm. xii.

${ }^{8}$ Uka Tjandrasasmita (ed). Sejarah Nasional Indonesia III. (Jakarta: Pn Balai Pustaka, 1984), hlm. 188-195

${ }^{9}$ Ada informasi berbeda, sebagaimana disampaikan Ali Azis, tentang definisi musolla di negeri Iran. Di negara para mullah ini, istilah musolla dikenal sebagai tempat salat besar, semisal mesjid di Indonesia. Sedangkan mesjid merupakan tempat salat kecil, semisal musolla di Indonesia.
}

beberapa langgar menjadi tempat belajar agama tingkat dasar. Istilah lain yang hampersama dengan langgar adalah tajug dan surau. Langgar lebih dikenal di JawaMadura, ${ }^{10}$ tajug di Pasundan Jawa Barat, sedangkan surau digunakan secara luas di Minangkabau, Tanah Batak, Sumatera Tengah, Sumatera Selatan. Bahkan di Semenanjung Malaya dan Patani (Thailand Selatan) istilah surau juga dikenal. ${ }^{11}$ Sebagai institusi pendidikan nonformal, penyelenggaraan pendidikan langgar berlangsung jauh dari kesan formal sebagaimana terlihat di sekolah dan madrasah. Kendati demikian, jika dipahami lebih seksama, terdapat sejumlah unsur yang saling terkait dan membentuk sebuah sistem pendidikan langgar. Unsurunsur dimaksud meliputi tujuan, materi

Baca lebih lanjut dalam Ali Azis, "Negeri Mullah, Negeri Beribu Kisah", dalam AULA Majalah Nahdlatul Ulama, Nomor 11 Tahun XXXI, Nopember 2009, hlm. 51.

${ }^{10}$ Fenomena yang cukup unik tentang langgar terjadi di pulau Madura. Di wilayah ini ditemukan bangunan langgar di hampir setiap rumah penduduk, utamanya di daerah pedesaan. Bangunan langgar biasanya merupakan satu kesatuan dengan bangunan rumah, dapur, dan kandang (rumah hewan). Kesemuanya disebut tanéan, artinya halaman yang dikelilingi oleh rumah dan bangunan yang lain. Kalau komplek perumahan itu terdiri dari beberapa rumah, maka disebut tanéan lanjeng (halaman panjang). Bangunan langgar selalu berada di ujung halaman bagian barat sebagai simbolisasi lokasi Ka'bah yang merupakan kiblat orang Islam ketika melakukan ibadah salat.

${ }^{11}$ Definisi tentang langgar dapat dibaca dalam Azyumardi Azra, dkk, Ensiklopedi Islam 4 (Jakarta; Ichtiar Baru Van Hoeve, 2001), hlm. 318; Departemen Pendidikan dan Kebudayaan, Kamus Besar Bahasa Indonesia (Jakarta; Balai Pustakan, 1997), hlm. 561 dan 979; Harun Nasution, Ensiklopedi Islam Indonesia (Jakarta; Djambatan, 1992), hlm. 574; Ensiklopedi Nasional Indonesia (Jakarta; Delta Pamungkas, 1997), hlm. 303; Azyumardi Azra, Surau; Pendidikan Islam Tradsional dalam Transisi dan Modernisasi (Jakarta: Logos, 2003), hlm. 47; John M. Echols \& Hassan Shadily, an Indonesian-English Dictionary (Jakarta; Gramedia, 1994), hlm. 535. 
pelajaran, pengasuh, santri, metode, dan evaluasi.

Di tiap-tiap desa yang penduduknya telah menjadi muslim umumnya didirikan langgar atau masjid. Fasilitas tersebut bukan hanya sebagai tempat shalat saja, melainkan juga tempat untuk belajar membaca al-Qur'an dan ilmu-ilmu keagamaan yang bersifat elementer lainnya. Pendidikan di langgar di mulai dari mempelajari abjad huruf Arab (hijaiyah) atau kadang-kadang langsung mengikuti guru dengan menirukan apa yang telah dibaca dari kitab suci alquran.pendidikan di langgar di kelolah oleh seorang petugas yang disebut amil, modil, atau lebai (di sumatera) yang mempunyai tugas ganda, disamping memberikan do'a pada waktu upacara keluarga atau desa, juga berfungsi sebagai guru. Pelajaran biasanya diberikan pada tiap pagi atau petang hari, satu sampai dua jam. Pelajaran memakan waktu selama beberapa bulan, tetapi pada umumnya sekitar satu tahun.

Metode pembelajaran adalah murid duduk bersila dan guru pun duduk bersila dan murid belajar pada guru seorang demi seorang. Satu hal yang masih belum dilaksanakan pada pengajaran al-qur'an di langgar, dan ini merupakan kekurangannya adalah tidak diajarkannya menulis huruf Al-qur'an (huruf arab), dengan demikian yang ingin dicapainhanya membaca semata. Padahal menurut metode baru dalam pengajaran menulis, seperti halnya yang dikembangkan sekarang dengan metode iqra', dimana tidak hanya kemampuan membaca yang ditekankan, akan tetapi dituntut juga penguasaan si anak di dalam menulis.

Pengajaran al-qur'an pada pendidikan langgar dibedakan kepada dua macam, yaitu:
a. Tingkatan
rendah: merupakan tingkatan pemula, yaitu mulainya mengenal huruf al-qur'an sampai biasa

membacanya, diadakan pada tiap-tiap kampong, dan anak-anak hanya belajar pada malam hari dan pagi hari sesudah sholat shubuh.

b. Tingkatan atas, pelajarannya selain tersebut diatas, ditambah lagi pelajaran lagu, qasidah, berzanji, tajwid serta mengaji kitab perukunan.

Adapun tujuan pendidikan dan pengajaran di langgar adalah agar anak didik dapat membaca al-qur'an dengan berirama dan baik, tidak dirasakan keperluan untuk memahami isinya. Mereka yang kemudian berkeinginan melanjutkan pendidikannya setelah memperoleh bekal cukup dari langgar/masjid di kampungnya, dapat masuk ke pondok pesantren.

\section{System Pendidikan Pesantren}

Perkataan pesantren barasal dari kata santri, dengan awalan pe dan akhiran an, bararti tempat tinggal santri. ${ }^{12}$ Menurut Manfred Ziemek menyebutkan bahwa secara etimologi pesantren barasal dari kata pe-santri-an, berarti "tempat santri". ${ }^{13}$ Versi Ensiklopedi Islam memberi gambaran yang berbeda, menurutnya pesantren berasal dari bahasa tamil yang berarti guru ngaji atau bahasa India "sastria' dan kata "sastra" yang bebarti buku-buku suci, buku-buku agama atau ilmu tentang pengetahuan. ${ }^{14}$ Secara terminologi pesantren adalah lembaga pendidikan Islam untuk memahami, menghayati, dan mengamalkan ajaran agama Islam (tafaquh fiddina) dengan menekankan pentingnya moral agama Islam sebagai pedoman hidup sehari-hari. ${ }^{15}$

\footnotetext{
${ }^{12}$ Zamahsyari Dhofier, Tradisi pesantren, (Jakarta: LP3ES, 1984) hlm. 18.

${ }^{13}$ Manfret Ziamek, Pesantren Islamiche Bildung In Sozialen Wandel, Butche B. Soendjojo, (penj), (Jakarta: Guna Aksara,1986) hlm. 16

${ }^{14}$ Ictiar Baru Van Houve, Ensiklopedi Islam, (Jakarta: Ictiar Baru Van Houve, 1993) hlm. 107

${ }^{15}$ Mastuhu, Dinamika Sistem Pendidikan Pesantren: Suatu Kajian Tentang Unsur dan Nilai
} 
Sistem pendidikan adalah totalitas interaksi dari seperangkat unsur-unsur pendidikan dan bekarja sama secara terpadu, dan saling melengkapi satu sama lain menuju tercapainya tujuan pendidikan yang telah menjadi cita-cita bersama pelakunya. Jadi, sistem pendidikan pesantren adalah kumpulan dasar-dasar umum tentang bagaimana lembaga pendidikan di selenggarakan dalam rangka membekali pengetahuan kepada siswa yang di dasarkan kepada al-Qur'an dan sunah. ${ }^{16}$ Pesantren sebagai lembaga pendidikan merupakan sistem yang memiliki beberapa sub sistem, setiap sub sistem memiliki beberapa sub-sub sistem dan seterusnya, setiap sub sistem dengan sub sistem yang lain saling mempengarui dan tidak dapat dipisahkan. Sub sistem dari sistem pendidikan pesantren antara lain,

a. Aktor atau pelaku: Kyai; ustadz; santri dan pengurus

b. Sarana perangkat keras: Masjid; rumah kyai; rumah dan asrama ustadz; pondok dan asrama santri; gedung sekolah atau madrasah; tanah untuk pertanian dan lain-lain.

c. Sarana perangkat lunak: Tujuan; kurikulum; kitab; penilaian; tata tertib; perpustakaan; pusat penerangan; keterampilan; pusat pengembangn masyarakat; dan lain-lain. ${ }^{17}$

Setiap pesantren sebagai institusi pendidikan harusmemiliki ke-3 sub sistem ini, apabila kehilangan salah satu dari ke3nyabelum dapat dikatakan sebagai sistem pendidikan pesantren.

Sisten Pendidikan Pesantren, ( Jakarta: INIS, 1994) hlm. 6

${ }^{16}$ Ahmad Syahid (edt), Pesantren dan Pengembangan Ekonomi Umat, (Depag dan INCIS, 2002), hlm. 30-31.

${ }^{17}$ Ibid. hlm. 25

\section{Unsur-unsur Sistem Pendidikan Pesantren \\ Pesantren sebagai lembaga} pendidikan tidak bisa lepas dari beberapa unsur dasar yang membangunnya. Menurut Zamahsyari Dhofier dalam bukunya Tradisi Pesantren menyebutkan ada lima elemen, yaitu pondok, masjid, santri, pengajaran kitab-kitab klasik, kyai.

\section{Pondok (asrama untuk para santri)}

Istilah pondok berasal dari bahasa Arab funduq (فندق) yang berarti hotel, penginapan. ${ }^{18}$ Istilah pondok juga diartikan sebagai asrama. Dengan demikian pondok mengandung arti juga tempat tinggal. Sebuah pesantren pasti memiliki asrama (tempat tinggal santri dan kyai). Di tempat tersebut selalu terjadi komunikasi antara kyai dan santri dan kerjasama untuk memenuhi kebutuhannya, hal ini merupakan pembeda dengan lembaga pendidikan di masjid atau langgar. ${ }^{19}$

Ada beberapa alasan pokok pentingnya pondok dalam suatu pesantren, Yaitu: pertama, banyaknya santri yang berdatangan dari tempat yang jauh untuk menuntut ilmu kepada kyai yang sudah masyhur keahliannya. Kedua, pesantrenpesantren tersebut terletak di desa-desa, dimana tidak tersedia perumahan santri yang berdatangan dari luar daerah. Ketiga, ada hubungan timbal balik antara kyai dan santri, dimana para santri menganggap kyai sebagi orang tuanya sendiri. ${ }^{20}$

Disamping alasan-alasan di atas, kedudukan pondok sebagai unsur pokok pesantren sangat besar sekali manfaatnya. Dengan adanya pondok, maka suasana belajar santri, baik yang bersifat intra kurikuler, ekstrekurikuler, kokurikuler dan hidden kurikuler dapat dilaksanakan secara

\footnotetext{
${ }^{18}$ Ahmad Warson Munawir, Kamus Arab Indonesia, (Yogyakarta: unit pengadaan buku-buku ilmiah keagamaan pondok Pesantren Al- Munawir, 1964), hlm. 1154

${ }^{19}$ Hasbullah, Op. Cit., hlm. 132-137

${ }^{20}$ Zamahsyari Dhofier, Op. Cit. hlm. 46-47
} 
efektif. Santri dapat di kondisikan dalam suasana belajar sepanjang hari dan malam. Atas dasar demikian waktu-waktu yang digunakan siswa di pesantren tidak ada yang terbuang secara percuma. ${ }^{21}$

\section{Masjid}

Masjid secara harfiah adalah tempat sujud, karena tempat ini setidaknya seorang muslim lima kali sehari semalam melaksanakan sholat. Funsi masjid tidak hanya sabagai pusat ibadah (sholat) tapi juga untuk perkembangan kebudayaan lama pada khususnya dan kehidupan pada umumnya, termasuk pendidikan. ${ }^{22}$ Masjid sebagai tempat pendidikan Islam, telah berlangsung sejak masa Rasullah, dilanjutkan oleh Khulafaurrasidin, dinasti Bani Umayah, Fatimiah, dan diasti lainnya. Tradisi menjadikan masjid sebagai tempat pendidikan Islam, tetap di pegang oleh kyai sebagai pimpinan pesantren sampai sekarang. Dalam perkembangannya, sesuai dengan bertambahnya jumlah santri dan tingkat pelajaran, dibangun tempat atau ruangan-ruangan khusus untuk halaqohhalaqoh berupa kelas, sebagaimana yang sekarang menjadi madrasah-madrasah. Namun demikian masjid tetap menjadi tempat belajar mengajar, hingga sekarang kyai sering membaca kitab-kitab klasik dengan metode wetonan dan sorogan.Pada sebagian pesantren menggunakan masjid sebagai tempat I'tikaf, dan melaksanakan latihan-latihan, atau suluk dan dzikir, ataupun latihan-latihan lain dalam kehidupan tarekat dan sufi. ${ }^{23}$

\section{Santri}

Santri adalah siswa yang belajar di pesantren, santri dapat di golongkan

\footnotetext{
${ }^{21}$ Haidar Putra Daulay, Historitas dan Eksistensi Pesantren, Sekolah dan Madrasah. (Yoqyakarta: Tiara Wacana Yogya, 2001). hlm. 16

${ }^{22}$ Safrullah Salim (penyt), Masjid, (Jakarta: Pustaka Antara, 1983), Cet. 4, hlm. 117

${ }^{23}$ Zamahsyari Dhofier, Op. Cit. hlm. 49
}

menjadi dua kelompok, yaitu: Pertama. Santri mukim, yaitu santri yang berdatangan dari tempat yang jauh yang tidak memungkin dia untuk pulang kerumahnya, maka dia mondok (tinggal) di pesantren. Sebagai santri mukim mereka punya kewajiban-kewajiban tertentu; Kedua. Santri kalong, yaitu para siswa yang datang dari daerah-daerah sekitar pondok yang memungkin dia pulang kerumahnya masing- masing. Santri kalong ini mengikuti pelajaran dengan jalan pulang pergi antara rumah dan pesantren. ${ }^{24}$ Di dunia pesantren biasa juga biasa diperlakukan, seorang santri pindah dari satu pesantren ke pesantren yang lain, setelah seorang santri merasa cukup lama tinggal di pesantren. Biasanya kepindahannya itu untuk menambah dan mendalami suatu ilmu yang menjadi keahlian dari seorang kyai yang di datanganginya. Pada pesantren yang tergolong tradisioanal, lamanya santri bermukim tidak ditentukan pada lamanya dia bermukim atau kelas, tetapi pada seberapa banyak kitab yang telah di baca. Kitab kitab tersebut bersifat dasar, menengah, dan kitab-kitab besar. ${ }^{25}$ Pada awalnya, pesantren diselenggarakan untuk mendidik santri agar menjadi taat menjalankan agamanya dan berakhlak mulia. Tetapi dalam perkembangan selanjutnya, santri dituntut memiliki kejelasan profesi, maka banyak dari pesantren membuka pendidikan kejuruan dan umum dari sekolah, madrasah bahkan perguruan tinggi. ${ }^{26}$

\section{Kyai}

Kyai adalah tokoh sentral dalam sebuah pesantren, maju mundur pesantren di tentukan oleh wibawa dan kharismati kyai. Bagi pesantren kyai adalah unsur yang paling dominan. Kemasyhuran,

\footnotetext{
${ }^{24}$ Ibid. hlm. 51-52.

${ }^{25}$ Haidar Putra Daula, Op.Cit. hlm. 15.

${ }^{26}$ Ibid. hlm. 51-52.
} 
perkembangan dan kelangsungan hidup suatu pesantren tergantung dari kedalaman dan keahlian ilmu serta kemampuannya dalam mengelola pesantren. Dalam konteks ini kepribadian kyai sangat menentukan sebab terhadap keberadaan pesantren karena dia sebagai tokoh sentral dalam pesantren. Gelar kyai diberikan oleh masyarakat yang memiliki pengetahuan mendalam tentang agama Islam dan memiliki serta memimpin pondok pesantren serta mengajarkan kitab-kitab klasik kepada para santri. Dalam perkembangannya kadang-kadang sebutan kyai diberikan kepada mereka yang memiliki pengetahuan mendalam tentang agama Islam, dan tokoh masyarakat walaupun tidak memiliki pesantren, pemimpin dan mengajar di pesantren, umumnya mereka adalah alumni pesantren. $^{27}$

Pengajian kitab-kitab Islam klasik Unsur pokok lain yang membedakan pesantren dengan lembaga pendidikan lain adalah bahwa dipondok pesantren diajarkan kitab-kitab klasik yang dikarang oleh zaman dulu (kitab kuning), mengenai berbagai macam ilmu pengatahuan agama Islam dan bahasa Arab. Pelajaran diberikan mulai dari yang sederhana, kemudian dilanjutkan dengan kitab-kitab tentang berbagai ilmu yang mendalam. Dan tingkatan suatu pesantren dan pengajarannya biasanya biasaanya di ketahui dari jenis kitab-kitab yang di ajarkannya. Kriteria kemampun membaca dan mengarahkan kitab bukan saja merupakan kriteria diterima atau tidaknya seorang sebagai ulama, atau kyai pada zaman dulu, tapi juga pada saat sekarang. Salah satu persyaratan seorang dapat di terima menjadi seorang kyai dari kemampuannya dalam membaca kitabkitab tersebut. Kitab-kitab klasik yang dibaca di pesantren dapat di golongkan

\footnotetext{
${ }^{27}$ Hasbullah Op.Cit. hlm. 144
}

menjadi 8 kelompok: yaitu: nahwu/sharaf; fiqih; ushul fiqih; hadits; tafsir; tauhid; tasauf dan etika, serta cabang-cabang ilmu lain seperti tarikh dan balaghah. ${ }^{28}$

\section{Perkembangan Pendidikan Islam}

\section{Lembaga Pendidikan Islam Tradisional: Dari Nggon Ngaji sampai Pesantren}

Pada awal abad ke-19, sistem pendidikan di Indonesia masih bersifat tradisional dan hanya dikenal satu jenis pendidikan yang disebut dengan "lembaga pengajaran asli" atau sekolah agama Islam yang berbentuk masjid, langgar, surau dan pesantren. Pendidikan dasar disebut nggon ngaji, sementara pendidikan lanjutannya adalah pondok pesantren yang keduanya tidak terdapat keterkaitan secara formal. ${ }^{29}$ Sistem pendidikan ini menitikberatkan pada pembelajaran baca al-Qur'an, pelaksanaan sholat dan pengetahuanpengetahuan yang terkait degan pokokpokok ajaran agama. Nggon Ngaji ini tidak terlembaga secara baik. Dalam perkembangan selanjutnya, setelah Indonesia merdeka dan disusul dengan berdirinya Depaetemen Agama, lembagalembaga non formal tersebut mulai disempurnakan kurikulumnya, sistem pendidikan sehingga memunculkan lembaga pendidikan yang disebut madrasah diniyah. ${ }^{30}$

Selain nggon ngaji yang mayoritas terdapat di Jawa, di Sumatra juga dikenal lembaga pendidikan Islam yang disebut Surau. Sebelum datangnya Islam, di Minangkabau telah ada surau yang fungsinya bukan seperti sekarang yang telah mengalami Islamisasi, melainkan sebagai tempat menyembah arwah nenek moyang. Menurut para ahli sejarah, Surau yang ada di Sumatra Barat ini pertama kali berdiri pada masa Raja Adityawarman

\footnotetext{
${ }^{28}$ Ibid, hlm. 50

${ }^{29}$ Nor Huda, Islam Nusantara, hlm. 370.

${ }^{30}$ Ibid, hlm. 375 .
} 
pada tahun 1356 di kawasan bukit Gombak.Kerajaan Adityawarman adalah kerajaan yang memiliki latar belakang Hindu-Budha. ${ }^{31}$ Hal ini menjadi jelas bahwa lembaga-lembaga pendidikan Islam pada awalnya adalah sebuah lembaga dengan tradisi non Islam yang dalam perkembangannya mengalami Islamisasi karena dirasa ada kemiripan dalam proses pembelajaran.

Bukan hanya Surau, Istilah Pesantren yang dalam perkembangan merupakan lembaga pendidikan Islam, adalah diambil dari kata santri, dengan imbuhan pe-an yang berarti tempat tinggal santri. Oleh $\mathrm{C}$. C Berg, kata santri ini dianggap kata turunan dari istilah shastri bahasa India yang berarti orang yang tahu buku suci agama Hindu. Bahkan menurut de Graff dan Pigeaud, pesantrem merupakan kelanjutan dari lembaga sejenis zaman praIslam di Indonesia yang disebut dengan mandala dan ashrama. Kedua lembaga ini adalah sebagai tempat pertapaan-pertapaan yang meskipun secara kelembagaan telah mengalami transformasi ke dalam bentuk pesantren, namun raktek-praktek pertapaan pra-Islam ini masih tetap dipertahankan. ${ }^{32}$ Proses belajar mengajar yang diajarkan di surau adalah pengajan al-Qur'an, ibadah, keimanan dan akhlaq. Pengajaran alQur'an diajarkan secara tradisional melaui metode bagdadiah yaitu dengan mengurutkan huruf-hijaiyah. Ibadah diajarkan secara praktis. Materi tentang Iman diajarkan melalui nyanyian, sementara akhlaq diajarkan melalui cerita.

Pada abad ke-20, Sistem pendidikan Surau mengalami degradasi dan kemudian berkembang menjadi pesantren. Pendidikan Pesantren adalah salah satu tradisi luhur dalam pendidikan dan pengajaran di Indonesia yang oleh para sejarawan terdapat perbedaan pendapat mengenai asal-usul pesantren. Sebagian

\footnotetext{
${ }^{31}$ Khozin, Jejak-jejak, hlm. 77.

${ }^{32}$ Nor Huda, Islam Nusantara, hm. 378.
}

beranggapan bahwa pesantren adalah tradisi pendidikan pra-Islam, sedang yang lain berpandangan bahwa pesantren adalah murni tradisi Islam. Pola pendidikan di pesantren adalah pola yang sangat unik. Terdapat relasi yang harmonis antara santri dan kyai dengan masjid sebagai pusat aktifitas. Keunikan yang lain adalah sistem pembelajaran dengan menggnakan metode sorogan dan weton. Yang pertama adalah santri menghadap kyai seorang demi seorang dengan membawa kitab yang akan dipelajarinya. Kyai membacakan kalimat demi kalimat, menerjemahkan dan menjelaskan maksudnya kemudian santri menyimak. Adapun metode yang kedua adalah metode kuliah, yang mana santri mengikuti pelajaran dengan duduk di skeliling kyai.

Sekalipun sebagai tradisi yang berakar lama dalam budaya Islam Indonesia, pesantren telah ada sejak beberapa abad sebelumnya dan dapat dilihat sebagai kelanjutan tradisi mapan serupa di negeri-negeri Islam dari kalangan kaum Sufi seperti tradisi zawiyah dan ribath di India dan Timur Tengah, namun suatu kenyataan yag sangat menarik ialah bahwa sistem pendidikan tradisional Islam itu berkembang pesat pada peralihan abad yang lalu. Pesantren-pesantren besar di kompleks Jombang-Kediri seperti Tebuireng, Tambakberas, Rejoso, Denayar, Jampes, Lirboyo dll yang kelak pengaruhnya begitu besar pada kehidupan nasional, antara lain melalui organisasi Nahdatul Ulama tumbuh dan berkembang kurang lebih sebagai saingan sekolahsekolah formal colonial. ${ }^{33}$

\section{Lembaga Pendidikan Islam Formal}

Madrasah yang berkembang di Indonesia berbeda dengan perkembangan

\footnotetext{
${ }^{33}$ Nurcholish Madjid, Islam Doktrin dan Peradaban: Sebuah Telaah Kritis tentang Masalah Keimanan, Kemanusiaan dan Kemodernan. (Jakarta: Paramadina, 2000), hlm. xii.
} 
madrasah yang ada di Timur Tengah. Madrasah di Indonesia merupakan perkembangan lebih lanjut atau pembaruan dari pesantren dan surau, ${ }^{34}$ sementara madrasah yang ada di timur tengah pada abad pertengahan serupa dengan lembaga pesantren yang ada di Indonesia. Di samping terdapat unsur-unsur seperti pesantren yaitu masjid, asrama dan ruang belajar, madrasah di Timur Tengah memiliki syaikh atau professor sebagai pemegang otoritas. ${ }^{35}$ Dalam konteks Indonesia, ini seperti keberadaan seorang kyai di pesantren. Meskipun sejarah pertumbuhan madrasah di Indonesia dipandang memiliki latar belakang sejarah yang berbeda dari madrasah yang ada di Timur Tengah, namun keberadaannya tidak dapat dilepaskan dari pengaruh pembaruan pendidikan Islam di Timur Tengah.

Perkembangan Madrasah pada abad Modern ini terjadi pada kurun awal abad ke-20 di mana pendidikan Islam mulai mengadopsi mata pelajaran non keagamaan. Latar belakang pertumbuhan ini tidak dapat dilepaskan dari gerakan pembaruan di Indonesia dan adanya respon pendidikan Islam terhadap kebijakan pendidikan pemerintah Hindia-Belanda. Beberapa Ulama yang telah berjasa menggagas tumbuhnya madrasah di Indonesia, antara lain adalah Syekh Abdullah Ahmad, pendiri Madrasah Adabiyah di Padang pada tahun 1909, disusul pada tahun Syekh M. Thaib Umar mendirikan Madrasah School di Batusangkar, yang sempat tutup dan dibuka kembali pada tahun 1918 oleh Mahmud Yunus. Tahun 1923 madrasah ini berganti nama Diniyah School. Pada tahun yang sama, Madrasah Diniyah Putri didirikan oleh Rangkayo Rahmah elYunusiyah yang sebelumnya, pada tahun 1915 Zainuddin Labai al-Yunusi

\footnotetext{
${ }^{34}$ Ibid, hlm. 80

${ }^{35}$ Nor Huda, Islam Nusantara, hlm. 391.
}

mendirikan Madrasah Diniyah. ${ }^{36}$ Madrasah Diniyah ini kemudian berkembang di Indonesia, baik merupakan bagian pesantren, surau atau yang lain, seperti beberapa organisasi Islam kemasyarakatan yang banyak mengelola madrasah. Di antara organisasi-organisasi tersebut adalah Muhammadiyah, al-Irsyad, Perhimpunan Umat Islam (PUI), persatuan Tarbiyah Islamiyah (PERTI), al-Jami'atul Washliyah, al-ittihadiyah, Nahdatul Ulama' dan Persatuan Islam. ${ }^{37}$

Sejak lahirnya, madrasah memiliki sistem tersendiri yang menjadi ciri khas dan membedakannya dengan pesantren dan sekolah umum, yaitu adanya pemaduan pelajaran umum dan agama, meskipun pemaduan kurilkulum tidaklah sama antara satu madrasah dengan madrasah lain. secara historis, dapat dilihat bahwa madrasah telah mengelami perubahanperubahan. Pada tahap awal madrasah semata mengajarkan maata pelajaran agama, namun pada akhirnya, sesuai dengan tuntutan zaman, madrasah memasukkan mata pelajaran umum yang semula hanya sebagai pelengkap, Namun setelah keluarnya SKB tiga menteri pada tahun 1975 yaitu SK berdasarkan kesepakatan yaitu Departemen dalam Negeri, Departemen Agama dan Departemen Pendidikan dan Kebudayaan. Yang menjembatani adanya dikotomi ilmu-ilmu umum dan agama. Dengan SKB ini tidak ada lagi perbedaan mendasar antara lulusan madrasah dan sekolahn umum. Baik dalam kesempatan melanjutkan studi maupun kesempatan memperoleh peluang kerja. Dengan adanya SKB tiga mentri ini madrasah memasuki

\footnotetext{
${ }^{36}$ Mulyanto Sumardi, Bunga Rampai Pemikiran tentang Madrasah dan Pesantren. (Jakarta: Pustaka biru, 1980), hlm. 49.

${ }^{37}$ Penjelasan lebih rinci mengenai lembagalembaga pendidikan yang dikelola oleh masingmasing organisasi Islam tersebut, baca lebih lanjut, Haidar Putra Daulay, Sejarah Pertumbuhan, hlm. 96-99
} 
era baru, yang mana mata pelajaran umum dominan $70 \%$ namun, bukan berarti menafikan kedudukan mata pelajaran agama.Mengkaji sejarah Perguruan Tinggi Agama Islam dapat dilacak keberadaannya sejak didirikannya Sekolah Tinggi Islam oleh Persatuan Guru-guru Agama Islam (PGAI) Padang pada tanggal 9 Desember 1940 dengan pimpinan Mahmud Yunus. Sekolah Tinggi Islam ini semula membuka fakultas Tarbiyah dan Syari'ah. Pada tahun 1941, STI ini sempat tutup dengan terjdainya peristiwa Perang Dunia II.

Pada tahun 1945, gagasan mendiirikan STI kembali digulirkan sebagai kebijakan politik masyumi. Disamping berdirinya barisan Mujahidin yag bernama Hizbullah. Dalam rangka mendirikan lembaga ini dibentuklah kepanitian yang diketua oleh Drs. Mohammad Hatta. Kepanitiaan ini berhasil mendirikan STI pada 8 Juli 1945 bertepatan dengan 27 Rajab 1364 dengan pimpinan Prof. Abdul Kahar Mudzakkir. Tidak jauh dengan konsentrasi yang diterapkan pada awal berdirinya STI tahun 1940, pada pendirian selanjutnya ini STI juga mngknsentrasikan materi pembelajaran pada ilmu agama dan kemasyarakatan. Dalam perkembangannya, STI dilakukan perbaikan dan pengembangan dengan membuka fakultas non agama yaitu Hukum, Ekonomi dan Pendidikan. Dengan dibukanya fakultas baru pada STI ini, menjadikan STI juga berubah nama drai STI menjadi UII yang menjadikan tujuan lembaga juga bergeser dari lembaga pendidikan bagi calon ulama menjadi lebih umum dan bersifat sekuler.

\section{Sekolah Islam Terpadu}

Berdasarkan Undang-Undang Pendidikan Nasional tahun 1989, sekolah Islam harus mengikuti sistem sekolah negeri, maka sekolah Islam mengembil sepenuhnya kurikulum yang disusun dan dikeluarkan oleh Kemendiknas. Dengan demikian, tidak ada perbedaan antara Sekolah Islam dengan Sekolah umum (negeri). Yang membedakan mereka adalah, antara lain, penekanan khusus pada mata pelajaran (matpel) agama. Sekolah Islam memiliki jam matpel yang berhubungan dengan Islam lebih banyak, sehingga memiliki jam pelajaran lebih lama untuk matpel agama. Sekolah umum (negeri) juga mempunyai jam pelajaran agama dalam kurikulum mereka, karena matpel agama bersifat wajib dalam sisdiknas Indonesia, yang harus diajarkan sejak tingkat kanak-kanak hingga tingkat universitas. Hanya saja, pada sekolah umum (negeri), jam matpel agama sangatlah terbatas, yakni hanya dua jam per-minggu.

Sekolah Islam Terpadu menjadi sebuah fenomena dalam pendidikan. Pertama, secara historis memang bangsa Indonesia tidak akan pernah lepas dari nilai-nilai religius yang menjadi sumber dan daya kekuatan bangsa ini. Sesungguhnya yang memperjuangkan bangsa ini di garis depan adalah kaum santri yang siap berjuang dan berperang. Tapi, tidak semua ternyata memegang senjata, ada diplomat ulung seperti K.H. Agus Salim, Guru dari para Founding Fathers, HOS. Cokroaminoto, dua pendidir Ormas besar yang bertujuan untuk kemerdekaan bangsa, K.H. Hasyim Asy'ari (pendiri NU) dan K.H. Ahmad Dahlan (pendiri Muhammadiyah), negarawan seperti M. Natsir atau seorang tokoh militer bintang lima seperti Jenderal Soedirman dan begitu banyak lagi. Mereka adalah para tokoh pesantren dan santri yang berjuang berdasarkan kemampuan dan kapasitas masing-masing.

Kedua, pada dasarnya manusia selalu ingin kembali kepada fitrahnya, setelah sekian lama manusia Indonesia dicekoki dengan sistem sekuler walau disamarkan membuat jiwa bangsa ini memberontak. 
Upaya-upaya untuk mencerabut bangsa ini dari akar budayanya ternyata tidak berhasil. Masyarakat bosan dengan Sistem Pendidikan Nasional dan model pendidikan umum yang terus memisahkan antara pendidikan agama (Islam) dengan pendidikan umum. Itulah fitrah manusia yang ingin memenuhi relung jiwanya dengan cahaya Allah SWT.

Ketiga, Sekolah Islam Terpadu menawarkan hal yang lebih dibandingkan dengan pendidikan umum. Selain mengintegrasikan pendidikan agama dengan pendidikan umum, Sekolah Islam Terpadu juga memberikan siswanya skill sesuai dengan bakatnya masing-masing. Selain itu, pola pembelajarannya juga sedikit berbeda dan memang mengakomodir hak-hak siswa sebagai penuntut ilmu. Hal ini sebenarnya mencoba menjawab tantangan zaman yang ke depan akan masuk pada era globalisasi dan perdagangan bebas. Anak-anak Indonesia harus sudah dibekali cara-cara manajerial, skill dan sebagainya yang menunjang dirinya untuk mampu bersaing. Tentunya membentuk karakter mereka bukan untuk menjadi tenaga kerja tetapi yang membuka lapangan kerja. Hal itulah yang membuat Sekolah Islam Terpadu sangat diminati oleh sekian banyak masyarakat Indonesia saat ini. ${ }^{38}$

Ketiga hal di atas bisa menjadi dasar untuk mencoba menerapkan sistem pembelajaran yang dilakukan di Sekolah Islam Terpadu (SIT), sehingga tidak melulu nilai angka yang diprioritaskan. Tapi mulai mengarah kepada nilai akhlak yang dimiliki anak didik nantinya. Fakta di lapangan mengenai cara mendidik di sekolah umum sangat berbeda dengan sekolah Islam terpadu yaitu dalam 'mengolah' anak didik mereka menjadi

\footnotetext{
${ }^{38}$ Sumantri, Elly. 2011. Fenomena Madrasah Bubar Dan Islamic Full Day School. /http://ellysumantri. blogspot. com/2010/06/ sekolah-islam-terpadu-fenomena. html)
}

sumber daya manusia yang juga pintar secara perilaku. Misalnya saja, tidak kita temukan semacam permainan berhikmah di sekolah umum, berdoa pun tidak bisa dilafalkan dan dibenarkan panjang pendek serta makhorijul hurufnya karena dalam 1 kelas mungkin ada siswa yang beragama lain. Selain itu, yang lebih penting adalah seluruh mata pelajaran mulai dari eksak sampai sosial disampaikan tanpa bisa terpadu dengan agama Islam, hanya sesuai dengan capaian tersampaikannya materi tersebut. Masyarakat mulai sadar dan melihat bahwa pendidikan di sekolah dasar merupakan pondasi dari pendidikan selanjutnya. Pembentukan kecerdasan tidak hanya dinilai dari umum tapi juga agama, khususnya agama Islam. Masa pendidikan dasar adalah masa pendidikan moral. Hal ini yang akan menentukan bagaimana anak berkembang. Kemerosotan moral yang terjadi pun juga disebabkan salah satunya oleh penanaman nilai agama pada anak usia dini yang diabaikan. ${ }^{39}$

Berbagai metode pengajaran di sekolah Islam terpadu yang menarik siswa untuk lebih paham dan kemudian mengikuti apa yang diajarkan ustadz/ustadzah mereka antara lain sebagai berikut: kelas diawali dengan membaca doa akan belajar, syahadat, surat fatihah, murojaah (mengulang hafalan), ikrar, tata tertib, dan absensi. Selanjutnya pembelajaran materi al-islam dengan menggunakan pendekatan belajar melalui bermain. Kelebihan yang dimikili oleh sekolah Islam terpadu yaitu prinsip learning by doing. Siswa terlibat langsung dalam, pengalaman yang konkrit dengan suatu materi. Aktivitas di mana mereka berpartisipasi dengan sesuatu yang relevan

\footnotetext{
${ }^{39}$ Dewi, Citra. 2010. Implementasi Sistem Pembelajaran Terpadu di Sekolah Dasar Islam Terpadu (SDIT) Ar Risalah Surakarta. Tesis Prodi Teknologi Pendidikan Universitas Sebelas Maret. Surakarta.
} 
dan penuh arti. Kemudian juga adanya reward and punihsment yang mendidik, jika salah seorang anak didik melakukan kesalahan maka respon yang dilakukan oleh ustadz/ustadzahnya bukanlah memarahi mereka, justru mengajak dialog hingga anak didik tahu benar dimana letak kesalahan yang dia lakukan. Dengan cara ini diharapkan anak didik tidak mengulangi kesalahannya lagi karena mereka telah paham bahwa perbuatannya tidak benar. Pembiasaan lainnya lewat contoh pun juga berlaku sebaliknya, jika salah seorang pengajar melakukan kesalahan yang diketahui anak didiknya, misalnya ketika masuk kelas tidak mengucapkan salam, maka pengajar lainnya akan menegur dan menanyakan kepada anak didik lainnya bagaimanakah seharusnya perilaku yang benar. Dari kedua contoh tersebut dapat dilihat bahwa sang anak didik benar-benar mendapatkan contoh nyata yang harus mereka lakukan, sehingga mereka lebih mudah menirunya. Dalam sekolah islam terpadu, guru tetap memegang peranan yang penting dalam proses pendidikan, yaitu dalam penanaman nilai. Hal ini sesuai dengan yang diungkapkan Chomaidi bahwa "peranan guru bukan sekedar komunikator nilai, melainkan sekaligus sebagai pelaku dan sumber nilai yang menuntut tanggung jawab dan kemampuan dalam upaya meningkatkan kualitas pembangunan manusia seutuhnya, baik yang bersifat lahiriyah maupun yang bersifat batiniah. ${ }^{40}$

\section{Sekolah Berasrama}

Madrasah dan sekolah Islam berasrama, yang mengadopsi sistem pesantren, memiliki sejumlah keunggulan lainnya. Aspek metode, kurikulum, dan manajemen diciptakan sebagai

\footnotetext{
${ }^{40}$ Chomaidi. "Peranan Pendidikan dalam Upaya Meningkatkan Kualitas Sumber Daya Manusia”. Disampaikan di depan Rapat Senat Terbuka UNY, 15 Oktober 2005.
}

conditioning internalisasi nilai-nilai yang lebih paripurna. Sebab internalisasi nilai sangat bergantung pada lingkungan, selain pada pribadinya. Beberapa nilai yang umumnya didapatkan dalam madrasah dan sekolah Islam berasrama (yang mengadopsi sistem pesantren) atau bersatu dengan pesantren adalah sebagai berikut. ${ }^{41}$

a. Pembiasaan dan pembentukan jiwa keikhlasan, yakni pembentukan jiwa yang selalu bergantung dan berserah diri kepada Allah, selalu mengharap ridha Allah dalam beraktivitas baik dan menjauhi segala keburukan serta tidak didorong oleh ambisi, keuntungan jangka pendek, atau popularitas, tetapi semata-mata karena Allah. Jiwa keikhlasan ini termanifestasikan dalam kehidupan sehari-hari dalam komunitas dan menjadi identitas para siswa (santri).

b. Pembiasaan dan pembentukan jiwa kesederhanaan, tetapi agung. Sederhana bukan berarti pasif, nrimo, dan miskin, tetapi mengandung unsur kekuatan dan ketabahan batin. Di balik kesederhanaan tersebut terkandung jiwa besar, keberanian, progressif, dan kreatif dalam menghadapi perkembangan dinamika social. Kesederhanaan menjadi identitas khas dari para siswa (santri) muslim.

c. Pembiasaan jiwa kemandirian, yakni berusaha sekuat tenaga untuk mampu hidup mandiri, baik untuk urusan pribadi maupun untuk kemajuan ummah. Para siswa (santri) tidak dididik untuk mengantungkan hidupnya kelak hanya menjadi pegawai (terutama PNS) tetapi juga ditanamkan jiwa wirausaha dan enterpereneuship. Siswa (santri) terbiasa menghadapi berbagai tekanan (persoalan) dan mencari solusi cerdasnya sendiri.

${ }^{41}$ Armai Arief, Tranformasi Pendidikan Islam, (Jakarta: CSRD Press, 2005), hlm. 50-51 
d. Pembiasaan dan pembentukan ukhuwah Islamiyyah yang demokratis. Situasi dialogis dan akrab antarkomunitas asrama (pesantren) yang dipraktekkan sehari-hari, disadari atau tidak, akan mewujudkan suasana damai, serta senasib dan sepenanggungan yang dapat membantu pembentukan dan pengembangan idealism kolektif para siswa (santri). Perbedaan kulur, primordialisme, suku, ras, dan status social (orang tuanya), tidak menjadi jalangan untuk membentuk jalinan pertemanan dan persaudaraan yang dilandasi oleh spiritualitas Islam yang tinggi.

e. Pembiasaan dan pembentukan jiwa yang "bebas" (tidak terlalu bergantung pada yang lain) atau bebas tekanan "politis", dan optimistik terhadap berbagai persoalan yang dihadapi.

Di madrasah dan sekolah Islam tidak terdapat diskriminasi gender. Siswa lakilaki dan perempuan diposisikan secara sama (equality), yakni mempunyai kesempatan yang sama untuk mendapatkan ilmu, pengetahuan, teknologi, dan seni(ipteks). Keduanya dapat bersaing untuk mendapatkan prestasi setinggitingginya, tanpa melalaikan kodrat masingmasing. Selain keduanya dipersiapkan untuk menghadapi berbagai kesempatan dan hambatan di wilayah public (pekerjaan dan pemerintahan), mereka juga dipersiapkan dengan berbagai keilmuan yang beroreientasi pada keluarga. Pada aspek pengetahuan "berkeluarga" ini, pendidikan madrasah dan sekolah Islam memperkenalkan berbagai ilmu untuk membangun keluarga sakinah mawaddah wa rahmah. Jelas materi ini tidak banyak ditemui di sekolah umum.

Dengan segala keunggulan desain pendidikan yang dimiliki sekolah Islam dan madrasah elit seperti di atas, maka tidaklah heran jika keberadaan mereka semakin menanjak popularitasnya. Dengan demikian, berbeda dengan situasi pada masa penjajahan Belanda, masa orde lama, dan masa orde baru, di mana banyak kaum muslim yang malu, bahkan menutupi identitas kemuslimannya, kini banyak kaum muslim yang bangga dengan identitas kemuslimannya. Sebagaimana dikatakan Nakamura bahwa Islam tengah menjadi identitas yang dibanggakan, sesuatu yang indah. Keberadaan sekolah Islam dan madrasah elit tidak hanya menjadi simbol dari kebanggaan muslim tentang lembaga pendidikannya, tetapi juga menjadi wahana pendidikan bagi generasi penerus agar bangga menjadi umat Islam. Equivalensi antara madrasah dan sekolah Islam dengan sekolah umum, pada sisi lain, memunculkan sejumlah konsekuensi yang tidak diharapkan (unintended consequences) dan tidak mudah dicarikan solusinya. Misalnya, penerapan equibalensi tersebut mengharuskan madrasah dan sekolah Islam menerapkan kurikulum sekolah umum yang ditetapkan oleh Kementrian Pendidikan Nasional, dari mulai kurikulum 1994 hingga Kurikulum Tingkat Satuan Pendidikan (KTSP). Pada sisi lain, untuk memelihara"karakter pendidikan Islam", madrasah dan sekolah Islam harus memiliki bobot mata pelajaran agama lebih banyak. Hasilnya, beban pelajaran secara keseluruhan di madrasah dan sekolah Islam, umumnnya, lebih berat dibandingkan sekolah umum.

Konsekuensi lebih berdampak luas lainnya adalah pada tingkat MA, jurusanjurusan yang dikembangkan juga mengikuti pola penjurusan yang ada di SMU, khususnya IPA, IPS, dan Bahasa. Hasilnya, jurusan-jurusan inilah yang kemudian dominan di MA, termasuk MA yang ada di Pesantren. Bahkan kemudian juga popular MA yang lebih menekankan pada keterampilan (vicasional), sehingga lebih merupakan vocational school). Yang tragis, sebagaimana telah disinggung, adalah nasib dari MAPK, madrasah yang 
awalnya diprioritaskan menjadi unggulan MA, kini termarjinalkan. Apalagi ketika MAPK ini tidak terdapat dalam nomenklatur UU Sisdiknas tahun 1989 dan 2003. Lebih jauh lagi, pada tahun yang lalu, Departemen Agama RI menghapuskan MAPK dan menjadikannya sebagai jurusan belaka pada sistem MA yang telah didominasi jurusan-jurusan umum. Azyumardi Azra menyebutkan bahwa hal ini merupakan indicator dari marginalisasi tafaqquh fi al-dîn pada tingkat MA yang menimbulkan dampak luar biasa terhadap perguruan tinggi Islam. $^{42}$

Dalam kondisi seperti ini madrasah dan sekolah Islam yang berasrama memiliki sistem yang cukup memadai untuk pencapaian tafaqquh fi al-dîn. Beban kurikulum madrasah, apalagi sekolah Islam, dapat ditunjang dengan pembelajaran keislaman di pesantren atau asrama. Namun, hal yang tidak mudah juga untuk menyinergikan kurikulum madrasah dan sekolah Islam, dengan kurikulum pesantren atau asrama, karena beberapa hal. Pertama, perbedaan orientasi kurikulum madrasah dan sekolah Islam dengan pesantren atau asrama. Madrasah dan sekolah Islam mengejar materi dan kurikulum yang dipatok pemerintah, sementara pesantren dan sekolah Islam mengejar materi dan kurikulum pesantren. Kedua, pengelola dan pengajar pada keduanya terkadang berbeda, yang juga membedakan susut pandang dan metode pengejaran, termasuk pencapaian kompetensi peserta didik. Bahkan tidak sedikit ditemukan sejumlah "friksi" antara pengelola pesantren (dan asrama) dengan pengelola madrasah dan sekolah Islam.

hlm. xvi

\footnotetext{
${ }^{42}$ Azra, "Wajah Baru Pendidikan Islam",
}

\section{E. Kesimpulan}

Pertumbuhan dan perkembangan Islam di Indonesia sebenarnya sudah dapat dilacak sejak masuknya Islam ke bumi Nusantara, meskipun belum terlembaga secara sistematis. Lembaga pendidikan islam tradisional di Nusantara antara lain yaitu: Masjid, Langgar, Pesantren adalah lembaga pendidikan dan pengajaran agama, umumnya dengan cara nonklasikal. Lembaga pendidkan islam modern diantaranya yaitu Madrasah di Indonesia merupakan perkembangan lebih lanjut atau pembaruan dari pesantren atau surau yang berlanjut pada Perguruan Tinggi Agama.

Sekolah Islam dan madrasah unggulan menambahkan penekanan pada religiusitas dan kesalehan melalui berbagai matpel keislaman. Secara sederhana, proses pendidikan yang dikembangkan di madrasah dan sekolah Islam bertujuan untuk mencetak alumni yang "cerdas" dan "berakhlak mulia". Faktor yang menumbuh kembangkan keberadaan sekolah dan madrasah; kesadaran sebagian muslim untuk mendesain system pendidikan unggul, menurunnya proses dan hasil pendidikan di sekolah-sekolah umum, skeptisnya sebagian masyarakat terhadap proses dan hasil pendidikan pada lembagalembaga pendidikan muslim yang ada.

\section{DAFTAR PUSTAKA}

Azyumardi Azra, Jaringan Ulama Timur Tengah dan Kepulauan Nusantara Abad XVII dan XVIII. (Bandung: Mizan, 1998)

Ali Azis, "Negeri Mullah, Negeri Beribu Kisah", dalam AULA Majalah Nahdlatul Ulama, Nomor 11 Tahun XXXI, Nopember 2009

Azyumardi Azra, dkk, Ensiklopedi Islam 4 (Jakarta; Ichtiar Baru Van Hoeve, 2001) 
Azyumardi Azra, Surau; Pendidikan Islam Tradsional dalam Transisi dan Modernisasi (Jakarta: Logos, 2003)

Zamahsyari Dhofier, Tradisi pesantren, (Jakarta: LP3ES, 1984)

Ahmad Syahid (edt), Pesantren dan Pengembangan Ekonomi Umat, (Depag dan INCIS, 2002)

Ahmad Warson Munawir, Kamus Arab Indonesia, (Yogyakarta: unit pengadaan buku-buku ilmiah keagamaan pondok Pesantren AlMunawir, 1964)

Armai Arief, Tranformasi Pendidikan Islam, Jakarta: CSRD Press, 2005

Chomaidi. "Peranan Pendidikan dalam Up aya Meningkatkan Kualitas Sumber Daya Manusia". Disampaikan di depan Rapat Senat Terbuka UNY, 15 Oktober 2005

Departemen Pendidikan dan Kebudayaan, Kamus Besar Bahasa Indonesia (Jakarta; Balai Pustakan, 1997)

Dewi, Citra. Implementasi Sistem Pembelajaran Terpadu di Sekolah Dasar Islam Terpadu (SDIT) Ar Risalah Surakarta. 2010.

Ensiklopedi Nasional Indonesia (Jakarta; Delta Pamungkas, 1997)

Hasbullah, Dasar-dasar Ilmu Pendidikan (Jakarta: RajaGrafindo Persada, 1999)

Harun Nasution, Ensiklopedi Islam Indonesia (Jakarta; Djambatan, 1992)

Haidar Putra Daulay, Historitas dan Eksistensi Pesantren, Sekolah dan Madrasah. (Yoqyakarta: Tiara Wacana Yogya, 2001).

Ira M. Lapidus, A History of Islamic Societies (United Kingdom: Cambridge University ress, 2002)
Ictiar Baru Van Houve, Ensiklopedi Islam, (Jakarta: Ictiar Baru Van Houve, 1993)

John M. Echols \& Hassan Shadily, Indonesian-English Dictionary (Jakarta; Gramedia, 1994)

Khozin, Jejak-jejak Pendidikan Islam di Indonesia: Rekonstruksi Sejarah Untuk Aksi (Malang: UMM Press, 2006)

Khozin, Menggugat Pendidikan Muhammadiyah (Malang, UMM Press, 2005)

Manfret Ziamek, Pesantren Islamiche Bildung In Sozialen Wandel, Butche $B$. Soendjojo, (penj), (Jakarta: Guna Aksara, 1986)

Mastuhu, Dinamika Sistem Pendidikan Pesantren: Suatu Kajian Tentang Unsur dan Nilai Sisten Pendidikan Pesantren, (Jakarta: INIS, 1994)

Mulyanto Sumardi, Bunga Rampai Pemikiran tentang Madrasah dan Pesantren (Jakarta: Pustaka biru, 1980)

M.C. Ricklelfs, Sejarah Indonesia Modern 1200-2004, terj. Satrio Wahono, dkk (Jakarta: Serambi Ilmu Semesta, 2007)

Nurcholish Madjid, "Merumuskan Kembali Tujuan Pendidikan Pesantren" dalam M. Dawam Rahardjo (ed), Pergulatan Dunia Pesantren: Membangun dari Bawah (Jakarta: P3M, 1985)

Nor Huda, Islam Nusantara: Sejarah Intelektual Islam di Indonesia (Yogyakarta: Ar-Ruzz Media, 2007),

Nurcholish Madjid, Islam Doktrin dan Peradaban: Sebuah Telaah Kritis tentang Masalah Keimanan, Kemanusiaan dan Kemodernan (Jakarta: Paramadina, 2000) 
Nurcholish Madjid, Islam Doktrin dan Peradaban: Sebuah Telaah Kritis tentang Masalah Keimanan, Kemanusiaan dan Kemodernan (Jakarta: Paramadina, 2000)

Safrullah Salim (penyt), Masjid, (Jakarta: Pustaka Antara, 1983), Cet. 4

Sumantri, Elly. Fenomena Madrasah Bubar Dan Islamic Full Day School. 2011
Uka Tjandrasasmita (ed). Sejarah Nasional Indonesia III. (Jakarta: Pn Balai Pustaka, 1984) 
